\title{
Study of Traces of Tritium at the World Trade Center
}

T.M. Semkow, R.S. Hafner, P.P Parekh, G.J. Wozniak, D.K. Haines, L. Husain, R.L. Rabun, P.G. Williams

This article was submitted to $23^{\text {rd }}$ American Chemical Society National Meeting, Orlando, FL, April 7-11, 2002

\section{October 1, 2002}

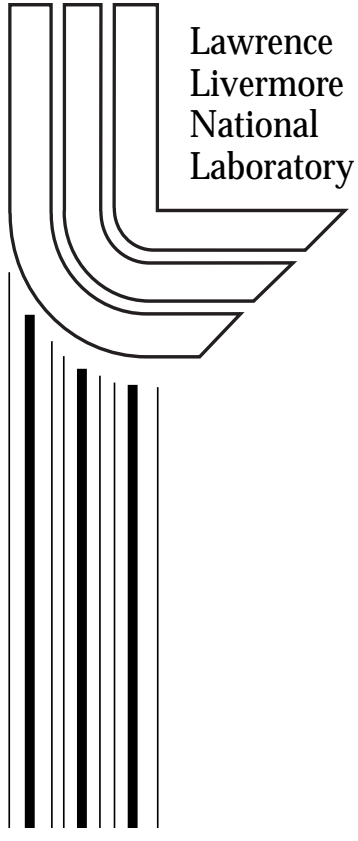




\section{DISCLAIMER}

This document was prepared as an account of work sponsored by an agency of the United States Government. Neither the United States Government nor the University of California nor any of their employees, makes any warranty, express or implied, or assumes any legal liability or responsibility for the accuracy, completeness, or usefulness of any information, apparatus, product, or process disclosed, or represents that its use would not infringe privately owned rights. Reference herein to any specific commercial product, process, or service by trade name, trademark, manufacturer, or otherwise, does not necessarily constitute or imply its endorsement, recommendation, or favoring by the United States Government or the University of California. The views and opinions of authors expressed herein do not necessarily state or reflect those of the United States Government or the University of California, and shall not be used for advertising or product endorsement purposes.

This is a preprint of a paper intended for publication in a journal or proceedings. Since changes may be made before publication, this preprint is made available with the understanding that it will not be cited or reproduced without the permission of the author.

This work was performed under the auspices of the United States Department of Energy by the University of California, Lawrence Livermore National Laboratory under contract No. W-7405-Eng-48.

This report has been reproduced directly from the best available copy.

Available electronically at http://www.doc.gov/bridge

Available for a processing fee to U.S. Department of Energy

And its contractors in paper from

U.S. Department of Energy

Office of Scientific and Technical Information

P.O. Box 62

Oak Ridge, TN 37831-0062

Telephone: (865) 576-8401

Facsimile: (865) 576-5728

E-mail: reports@adonis.osti.gov

Available for the sale to the public from

U.S. Department of Commerce

National Technical Information Service

5285 Port Royal Road

Springfield, VA 22161

Telephone: (800) 553-6847

Facsimile: (703) 605-6900

E-mail: orders@ntis.fedworld.gov

Online ordering: http://www.ntis.gov/ordering.htm

OR

Lawrence Livermore National Laboratory

Technical Information Department's Digital Library

http://www.llnl.gov/tid/Library.html 
Proceedings of the Symposium on Radioanalytical Methods at the Frontier of Interdisciplinary Science: Trends and Recent Achievements. 223 $3^{\text {rd }}$ American

Chemical Society National Meeting, Orlando, FL, April 7-11, 2002

\title{
Study of Traces of Tritium at the World Trade Center ${ }^{\star}$
}

\author{
Thomas M. Semkow ${ }^{\mathrm{a}, \mathrm{b}, \oplus \text {, Ronald S. Hafner }}{ }^{\mathrm{c}}$, Pravin P. Parekh ${ }^{\mathrm{a}}$, \\ Gordon J. Wozniak ${ }^{\text {d }}$, Douglas K. Haines ${ }^{a}$, Liaquat Husain ${ }^{\text {a,b }}$, \\ Robert L. Rabun ${ }^{\mathrm{e}}$ and Philip G. Williams ${ }^{\mathrm{f}}$ \\ ${ }^{a}$ Wadsworth Center, New York State Department of Health, Albany, \\ NY 12201 \\ ${ }^{b}$ School of Public Health, University at Albany, State University of New \\ York, Albany, NY 12201 \\ ${ }^{c}$ Fission Energy and Systems Safety Program, Lawrence Livermore \\ National Laboratory, Livermore, CA 94551 \\ ${ }^{d}$ Nuclear Science Division, E.O. Lawrence Berkeley National Laboratory, \\ Berkeley, CA 94720 \\ ${ }^{\mathrm{e}}$ Tritium Engineering Department, Westinghouse Savannah River \\ Company, Aiken, SC 29808 \\ ${ }^{\text {f}}$ Physical Biosciences Division, E.O. Lawrence Berkeley National \\ Laboratory, Berkeley, CA 94720
}

Traces of tritiated water (HTO) were detected at the World Trade Center (WTC) ground zero after the 9/11/01 terrorist attack. A water sample from the WTC sewer, collected on 9/13/01, contained $0.164 \pm 0.074(2 \sigma) \mathrm{nCi} / \mathrm{L}$ of HTO. A split water sample, collected on 9/21/01 from the basement of WTC Building 6, contained $3.53 \pm 0.17$ and $2.83 \pm 0.15 \mathrm{nCi} / \mathrm{L}$, respectively. These results are well below the levels of concern to human exposure. Several water and vegetation samples were analyzed from sites outside ground zero, located in Manhattan, Brooklyn, Queens, and the Kensico and Croton Reservoirs. No HTO above the background was found in those samples. Tritium radioluminescent (RL) devices were investigated as possible sources of the traces of tritium at ground zero. It was determined that the two Boeing 767 aircraft that hit the Twin Towers contained a combined $34 \mathrm{Ci}$ of tritium at the time of impact in their emergency exit signs. There is also evidence that many weapons from law 
enforcement were present and destroyed at WTC. Such weaponry contains by design tritium sights. The fate and removal of tritium from ground zero were investigated, taking into consideration tritium chemistry and water flow originating from the fire fighting, rain, as well as leaks from the Hudson River and broken mains. A box model was developed to describe the above scenario. The model is consistent with instantaneous oxidation of the airplane tritium in the jet-fuel explosion, deposition of a small fraction of HTO at ground zero, and water-flow controlled removal of HTO from the debris. The model also suggests that tritium from the weapons would be released and oxidized to HTO at a much slower rate in the lingering fires at ground zero.

\section{World Trade Center}

The World Trade Center was built in New York City during the 1960s through the 1980s. It contained seven buildings designated as WTC 1 through WTC 7. The most prominent were the 110-floor Twin Towers, WTC 1 - The North Tower built in 1970, and WTC 2 - The South Tower built in 1972. The WTC was owned and operated by the Port Authority of New York and New Jersey (PANYNJ). It is important to this investigation that several federal law enforcement agencies were located at the WTC $(1,2)$. US Customs and the Bureau of Alcohol Tobacco and Firearms (ATF) were housed in WTC 6, also called the US Customs House. US Secret Service, Central Intelligence Agency, and the New York City emergency command center had offices in WTC 7.

The original, 1776 Manhattan shoreline crossed the WTC complex in the north-south direction. The present-day land to the west of the complex is actually a fill (3). Since WTC 1 and 2 had to have foundations down to the bedrock, the required engineering solution was achieved by constructing the socalled Bathtub. It is surrounded by the Slurry Wall, $510 \mathrm{ft} \times 980 \mathrm{ft}$, 70-ft deep, and 3-ft thick (4). The Slurry Wall prevented leaks from the Hudson River. Besides the foundations of the buildings, the Bathtub contained a Concourse and a six-level basement underground. On the lowest B6 level there was a tunnel and a station for the Port Authority Trans-Hudson (PATH) train, providing commuting from and to New Jersey under the Hudson River. 


\section{The Terrorist Attack}

On September 11, 2001 at 8:46 AM, a Boeing 767-223ER aircraft operated by American Airlines as Flight 11 hit WTC Tower 1 causing jet fuel explosion and fire. At 9:02 AM, a second aircraft, a Boeing 767-222 operated by United Airlines as Flight 175, hit WTC Tower 2. Both flights originated in Boston, so the aircraft were full of fuel, estimated at 10,000 gallons each (5). WTC 2 collapsed after $47 \mathrm{~min}$, followed by WTC 1 which lasted $102 \mathrm{~min}$.

The collapse of the Towers has been studied in detail $(5,6,7)$. The floor trusses of the Towers were supported by the steel perimeter columns, while the central columns supported the elevator shafts. If there had been no fire, the Towers would have not collapsed. However, due to the fires, when temperature reached $1500 \mathrm{~F}$, the steel support systems lost their strength, causing the structures to collapse. By some estimates, the temperatures could have locally reached $1800 \mathrm{C}$ from burning of the aluminum bodies of the airplanes. At this temperature, hydrogen gas is evolved from burning of the concrete, which fuels further burning. The reasons that WTC 2 collapsed first included the higher speed of the aircraft at collision $(586 \mathrm{mph})$ compared to the speed of the aircraft colliding with WTC 1 (494 $\mathrm{mph})$, as well as noncentral and lower point of impact in the case of WTC 2. The collapsing Towers destroyed other WTC buildings, and the debris compacted and destroyed much of the Bathtub. The debris from WTC 1 plunged through the center of WTC 6, creating a pit stretching down to the basement of the Bathtub (8). At 5:30 PM, WTC 7 collapsed due to a weakening of its steel support structure caused by a diesel fuel fire. The fuel was stored in the tank for emergency power generation for the New York City emergency command center (9). The WTC area is referred to as ground zero.

Authorities determined that 2823 people died in the attack on the WTC (5), including 157 people onboard the aircraft, 343 New York City Fire Department firefighters, 23 officers from the New York City Police Department, 37 officers from the PANYNJ Police Department, and 3 officers from the New York Office of Court Administration $(10,11)$.

\section{Tritium Measurements}

Tritium is produced naturally in the atmosphere from the reactions of cosmic ray protons and neutrons with $\mathrm{N}$ and $\mathrm{O}$ nuclei, as well as by ternary fission in geological formations $(12,13,14)$. However, the bulk contribution to environmental accumulation comes from the nuclear testing in the atmosphere, nuclear fuel cycle, and some from consumer products. The total present-day 
inventory of tritium in the environment is $19 \mathrm{EBq}$, only $1.3 \mathrm{EBq}$ of which is attributed to natural production (15). The levels of tritium in the environment have been decreasing steadily, due to its decay with a half-life of 12.3 years, since the ban on atmospheric nuclear testing. Tritium occurs in the environment primarily as tritiated water, and much less as organically bound tritium. Typical current concentrations of HTO in water in the US are $0.1-0.2 \mathrm{nCi} / \mathrm{L}(16)$.

We became interested in the subject of tritium at WTC because of the possibility that tritium RL devices could have been present and destroyed at WTC. Three groups of environmental samples were analyzed for tritium as HTO, to confirm or disprove this hypothesis. The 1st group consisted of the samples collected by the EPA not specifically for tritium analysis. They were analyzed for tritium after this investigation had started. The 2 nd group was analyzed for tritium before this investigation started, and was collected by the New York City Department of Environmental Protection (samples 23-35 at the request of EPA). The 3rd group consisted of the samples collected especially for this investigation.

Water was distilled once from the environmental stationary water samples, and twice from the vegetation samples. $10 \mathrm{ml}$ of such distillate was mixed with $13 \mathrm{ml}$ of Instagel XF cocktail (Packard) in a borosilicate glass vial and measured on an ultralow-background liquid scintillation counter TRI-CARB, model $3170 \mathrm{TR} / \mathrm{SL}$ by Packard. The samples from groups 1 and 3 were measured for $200 \mathrm{~min}$, while from group 2 for $100 \mathrm{~min}$. The tritium end-point beta energy is $18.6 \mathrm{keV}$. We used the energy window $1-13 \mathrm{keV}$ to maximize signal to background ratio. The background rate was about $2 \mathrm{cpm}$. The efficiency of the instrument was calibrated using HTO standards as a function of the tSIE quench index. The environmental samples had a tSIE value around 230, corresponding to efficiency in the range $0.20-0.25$.

The results are given in Table I. Samples 1,6, and 7 are from ground zero and they are all positive. The rest of the results in Table I are upper limits. Sample 1, measuring $0.164 \pm 0.74 \mathrm{nCi} / \mathrm{L}$, is from the WTC sewer, collected three days after the attack, and is just above the detection limit. Samples 6 and 7 of about $3 \mathrm{nCi} / \mathrm{L}$ are split samples from WTC 6, basement B5, collected 10 days after the attack. Thus, tritium was detected in these samples from ground zero, but the concentrations are very low. In fact, $3 \mathrm{nCi} / \mathrm{L}$ is about 7 times less than the EPA limit in drinking water of $20 \mathrm{nCi} / \mathrm{L}$ (17). No health implications are known or expected at such low concentrations (13). As a consequence, no additional ground-zero samples were judged to be necessary.

Samples 2-5 are from roof tanks in South Manhattan near ground zero. Since these tanks are vented, there was a possibility of some atmospheric 
Table I. The results of tritium analysis in New York State.

\begin{tabular}{|c|c|c|c|c|c|}
\hline $\begin{array}{l}\text { Gr. } \\
\text { no }\end{array}$ & $\begin{array}{l}\text { Samp. } \\
\text { no }\end{array}$ & $\begin{array}{l}\text { Coll. } \\
\text { date }^{\mathrm{a}}\end{array}$ & $\begin{array}{l}\text { Samp. } \\
\text { type }\end{array}$ & Sampling location & $\begin{array}{l}\text { Activity }^{\mathrm{b}} \\
\text { (nCi/L) }\end{array}$ \\
\hline 1 & 1 & $9 / 14$ & water & WTC storm sewer & $0.164 \pm 74$ \\
\hline 1 & 2 & 9/17 & water & Manh., 55 Broadway, 32 fl., roof tank & $<0.13^{\mathrm{c}}$ \\
\hline 1 & 3 & $9 / 18$ & water & Manh., 111 Broadway, 22 fl., roof tank & $<0.13^{\mathrm{c}}$ \\
\hline 1 & 4 & $9 / 18$ & water & Manh., 45 Wall St., $30 \mathrm{fl}$. , roof tank & $<0.13^{\mathrm{c}}$ \\
\hline 1 & 5 & $9 / 18$ & water & Manh., 7 Hanover Sq., 29 fl., roof tank & $<0.13^{\mathrm{c}}$ \\
\hline 1 & 6 & $9 / 21$ & water & WTC 6, basement B5 & $3.53 \pm 17$ \\
\hline 1 & 7 & $9 / 21$ & water & same & $2.83 \pm 15$ \\
\hline 2 & $8-22$ & $9 / 11,12$ & water & Kensico and Croton Reservoirs ${ }^{\mathrm{d}}$ & $<0.11-<0.19$ \\
\hline 2 & $23-35$ & $9 / 15$ & water & South Manhattan water distribution & $<0.12-<0.15^{\mathrm{c}}$ \\
\hline 3 & 36 & $10 / 25$ & grass & Albany & $<0.12^{\mathrm{e}, \mathrm{f}}$ \\
\hline 3 & 37 & $10 / 27$ & grass & Brooklyn, Brooklyn Heights & $<0.21^{\mathrm{e}, \mathrm{f}}$ \\
\hline 3 & 38 & $10 / 27$ & water & Brooklyn, Govanus Canal & $<0.11$ \\
\hline 3 & 39 & $10 / 27$ & grass & Brooklyn, Govanus Park & $<0.091^{\mathrm{e}}$ \\
\hline 3 & 40 & $10 / 27$ & water & Brooklyn, English Kills & $<0.11$ \\
\hline 3 & 41 & $10 / 27$ & water & Brooklyn, Prospect Park & $<0.090$ \\
\hline 3 & 42 & $10 / 27$ & grass & same & $<0.093^{\mathrm{e}}$ \\
\hline 3 & 43 & $10 / 27$ & water & Brooklyn, Marine Park & $<0.11$ \\
\hline 3 & 44 & $10 / 27$ & grass & same & $<0.090^{\mathrm{e}}$ \\
\hline 3 & 45 & $10 / 27$ & water & Brooklyn, Paerdegat Basin & $<0.090$ \\
\hline 3 & 46 & $10 / 27$ & water & Brooklyn, Coney Island & $<0.11$ \\
\hline 3 & 47 & $10 / 27$ & grass & same & $<0.092^{\mathrm{e}}$ \\
\hline 3 & 48 & $10 / 27$ & water & Queens, Forest Park & $<0.090$ \\
\hline 3 & 49 & $10 / 28$ & water & Poughkeepsie & $<0.11$ \\
\hline 3 & 50 & $10 / 28$ & grass & same, with weeds & $<0.17^{\mathrm{e}, \mathrm{f}}$ \\
\hline 3 & 51 & $11 / 4$ & leaves & Manhattan, Battery Park & $<0.12^{\mathrm{e}, \mathrm{f}}$ \\
\hline
\end{tabular}

FOOTNOTES: a) In 2001; b) $2 \sigma$ errors or limits; c) System closed to atmospheric deposition; d) New York City raw water reservoirs in Westchester County; e) Activity given per volume of water extracted from the vegetation; f) Problems with chemiluminescence and color quench, measured with instrumental luminescence correction. The upper limits for samples 9 and 22 are higher because the efficiency was lower due to higher quench (lower tSIE index), the detection limit being inversely proportional to the efficiency.

contamination, although restricted. Samples 23-35 are from the New York City water distribution system in South Manhattan, which is closed to the atmospheric deposition. All of these samples do not show any tritium present, as 
expected. There was also a possibility that some HTO would have been transported with the fire plume during the first several days after the attack and deposited downwind. The wind direction was approximately northwest during 9/11 and 9/12 (18). Therefore, we did environmental sampling in Brooklyn, Queens, and South Manhattan, which are downwind from ground zero. The sample numbers are 37-48 and 51 in Table I. They were taken about seven weeks after the attack. All the results were zero within the detection limits, which is consistent with the low levels of HTO detected at ground zero.

\section{Tritium Radioluminescent Devices}

The difference between tritium RL devices and CRT tubes is that, in the former, $\beta$ particles from tritium decay, rather than accelerated electrons, generate light in the phosphor (14). $\mathrm{ZnS}$ is the most widely used phosphor and is activated by an impurity. ZnS-Ag gives a green glow, with a decay constant of $0.2 \mu \mathrm{s}$. $\mathrm{ZnS}-\mathrm{Cu}$ gives blue-green light, and $\mathrm{ZnS}-(\mathrm{Cu}, \mathrm{Mg})$ gives yellow-orange light (19). There are two basic types of RL devices: i) gaseous tritium light sources (GTLS) sealed in borosilicate glass tubes, internally coated with the phosphor, and ii) tritium chemically incorporated into a polymer such as polystyrene and mixed with the phosphor. There is no tritium leakage from GTLS, unless broken. There is a small diffusion of tritium from polymers. GTLS are used as airport runway lights at remote airports (Alaska); emergency EXIT and other signs in buildings; emergency EXIT signs, handles, and aisle markers in airplanes; as well as sights in weaponry and markings in time devices. The polymer-based RLs are used in emergency signs and as paints in watches. When GTLS tubes age, they acquire a small percentage $(<2 \%)$ of HTO due to radiolytic reactions with the phosphor binder $(14,20,21)$.

Typical emergency EXIT signs in buildings contain from several to several tens of $\mathrm{Ci}$ of molecular tritium. The maximum recommended tritium activity by ANSI standard is $50 \mathrm{Ci}(22)$. The activity of tritium is regulated by the Nuclear Regulatory Commission (NRC), per request of a manufacturer. For instance, Mb-microtec ag registered with NRC sealed RL devices for up to $50 \mathrm{Ci}$ (19). The typical content of tritium per device is $10 \mathrm{Ci}$. The tritium emergency signs in airplanes have a regulatory limit of $10 \mathrm{Ci}(23)$.

GTLS are used extensively in weaponry and are standard equipment in military as well as law enforcement. Of interest to this work are gun sights containing GTLS capsules, either cylindrical or spherical, which facilitate aiming at night. There are two categories of interest: scopes and night sights. The content of tritium depends on the configuration as well as on the manufacturer. Trijicon Inc. uses $100 \mathrm{mCi}$ in scopes and three capsules of $18 \mathrm{mCi}$ 
each (54 mCi total) in night sights (24). Innovative Weaponry Inc. uses $54 \mathrm{mCi}$ in their PT night sights (25). Meprolight Ltd. uses between 30 to $54 \mathrm{mCi}$ per set of night sights (26).

Tritium in timing devices is used as GTLS or polymer paint. NRC regulations limit tritium content per timepiece to $25 \mathrm{mCi}$ for paint (27) and 200 $\mathrm{mCi}$ for GTLS (28). The ISO standard recommends for paints a maximum average activity of $5 \mathrm{mCi}$ per lot, and $7.5 \mathrm{mCi}$ per isolated instrument (29). The US military standard recommends the maximum activity for a GTLS device as $25 \mathrm{mCi}$ (30). A major manufacturer of GTLS-containing watches is $\mathrm{Mb}$ microtec ag, who offers the watches to the US market under the brand name Luminox. The watches are licensed with NRC under NR-0446-D-103-E for up to $100 \mathrm{mCi}$ of tritium; however, the watches on the market contain up to $41 \mathrm{mCi}$ of tritium (31). Luminox makes dive watches for the US Navy and aviator watches for the US Air Force. Consumer models are available. These types of watches are expensive, available through specialty stores only and are, therefore, not widely worn.

Less expensive and more popular watches use paint containing tritiated polymer, in a plastic casing. A major manufacturer of tritiated paint is Rc Tritec ag. The typical range of tritium activity per timepiece is $0.8-2.7 \mathrm{mCi}$ (32). However, a non-radioactive photoluminescent material, Super-LumiNova, has been developed by Nemoto \& Co., based on mixed aluminum oxides and activated with a rare earth element (19). It is characterized by high intensity and long afterglow, and is used in more than $95 \%$ of luminescent watches currently manufactured, instead of tritium paint (32).

\section{Sources and Fate of Tritium at WTC}

As described in Section 3, HTO was detected at ground zero at the very low concentrations. Several sources of tritium were considered and analyzed, as consistent with the experimental data: i) EXIT signs in the buildings, ii) emergency signs on the airplanes, iii) fire and emergency equipment, iv) weaponry, and v) timepieces.

Presence of RL EXIT signs in the buildings would have implied large available source of tritium. We were informed by PANYNJ authorities that there were no tritium signs at the WTC, only photoluminescent ones (33). This is entirely consistent with our observations.

It was determined by the Federal Aviation Administration that Boeing 767, Serial Number 21873, operated by United Airlines, Tail Number 767-222 
N612UA, was delivered in February, 1983, with $43.2 \mathrm{Ci}$ of tritium in emergency signs (34). The $43.2 \mathrm{Ci}$ of tritium was contained in four EXIT signs (10 Ci each) and four slide/raft handles $(0.8 \mathrm{Ci}$ each). The same activity of tritium was present upon the April, 1987 delivery of the second Boeing 767, Serial Number 22322, Tail Number 767-223ER N334AA, operated by American Airlines. Since neither of these aircraft were modified after delivery $(34,35)$, the total activity from the aircraft was $34 \mathrm{Ci}$ at the time of attack, when the radioactive decay of tritium has been accounted for.

The tritium from the airplanes was released at the two points of impact with the Towers. Conversion of molecular tritium $\left(\mathrm{T}_{2}\right)$ to HTO in the atmosphere is normally negligible: the formation of HTO through chemical kinetics is extremely slow (36). Rather, the conversion to HTO in atmospheric transport goes through a stage of deposition of molecular tritium to soil, followed by a microbial and exchange oxidation in soil. HTO is then directly reemitted, or taken up by plants first and then reemitted into the atmosphere. The combined process results in measured conversion rates of between $10^{-5}$ and $10^{-3}$ for downwind distances of up to $15 \mathrm{~km}$.

However, at each of the two points of impact there was an explosive release. Considering the jet fuel explosion and high-temperature fires at the WTC, $\mathrm{T}_{2}$ was efficiently oxidized to HTO, based on weapons-testing data (37), as well as laser heating experiments (38). This oxide immediately vaporized due to the intense heat. Most of the HTO would be transported in the vapor phase with the wind, since the weather was dry on 9/11/01 (18). One cannot accurately determine how much HTO condensed on building surfaces and deposited on the ground with the collapse of the buildings, but this would have been a small fraction of the $34 \mathrm{Ci}$ available. One indication is the low $0.164 \pm 0.74 \mathrm{nCi} / \mathrm{L}$ from the WTC sewer, collected two days after the attack. Since the initial source was small, it is consistent that the environmental samples collected downwind over seven weeks after the attack contained no tritium (Section 3).

It is important to compare this small release of tritium in the fire with two other incidents caused by fire and involving the release of molecular tritium. One incident involved a fire in a community building at Council, Alaska, on 9/6/87, where 12 RL light panels for airport runway marking were stored, totaling $3000 \mathrm{Ci}$ of tritium (39). It was a free-burning fire, which consumed the building in $1 \mathrm{hr}$. Tritium assessment was done 11 days after the accident. The remaining GTLS tubes were mostly undamaged but disfigured, indicating that all tritium had escaped. No air-borne tritium was detected. All tubes were carefully wiped on surfaces, and the HTO activity from the wipes amounted to $6.5 \times 10^{-8}$ of that originally present. No HTO was found in bioassay or environmental samples. The release scenario at the WTC from the airplanes is 
consistent with this accident. However, the Twin Towers collapsed before their complete burning, so the fraction of tritium deposited at the WTC might be larger. Another incident, involving containers with tens of thousands $\mathrm{Ci}$ of tritium, was a fire on a C-124 airplane on the ground at the Wright-Patterson Air Force Base, Dayton, $\mathrm{OH}$, on 10/12/65 (40). That fire was actively extinguished. Elevated levels of HTO were found in bioassay samples, on emergency and fire equipment, clothing, in the debris, as well as in the soil and water from nearby samples. In comparison with the Alaska incident, the active fire fighting contributed to capture of some of the HTO on site.

After the WTC buildings collapsed, fire fighting and rescue operations continued. The fires at ground zero were smoldering for months after the attack (41). It was determined that 3 million gallons of water were hosed on site in the fire-fighting efforts between $9 / 11$ and $9 / 21$ (the day of the tritium measurement; samples 6 and 7 in Table I) (42). In addition, there were two episodes of rain during the same 10-day period: on $9 / 14$ and $9 / 20,21$ (18), totaling 0.9 million gallons of water in the Bathtub area. Considering the neighboring areas, we take 1 million gallons from the rain. Therefore, a total of 4 million gallons of water percolated through the debris in the first 10 days and collected at the bottom of the Bathtub. The percolating water efficiently dissolved that part of the airplane HTO, which was deposited in the building collapse, and carried it to the bottom of the Bathtub.

An engineering assessment determined that there was a water leak into the Bathtub, adding to the rain and hose water. The main leak was from the Hudson River via two WTC cooling water outfall lines, while the incoming lines were shut down (43). There were reported leaks from broken water mains $(3,44)$. There were also problems with the water table due to a hole in the damaged Slurry Wall along Liberty Street (45). The combined water from rain and hoses, as well as the leaks, collecting at the bottom of the Bathtub, transferred into the PATH train tunnel. Water then flowed under the Hudson River to the Exchange Place Station, Jersey City, NJ, since it is lower in elevation than WTC B6 level $(3,43)$, where it was pumped out. Other pumps were installed (after 9/21) along Liberty Street to stabilize the Slurry Wall, which had moved (45). Based on the pumping records, a total of 30 million gallons of water passed through the Bathtub between 9/11 and 9/21 (4,46). Therefore, 26 million gallons were from the leaks. Even on 10/8/01 there was still some water flowing to New Jersey (44). HTO that collected at the bottom of the Bathtub was removed with the water flow. The 9/21 HTO sample, reportedly collected from basement B5, sampled that dynamic system close to the bottom of the Bathtub.

It was concluded that fire and emergency equipment could not have been a source of tritium, since such equipment does not typically use tritium RL 
devices, at least for the type of emergency response conducted at the WTC. Weaponry was another likely source of tritium. As described in Section 1, several federal and state law enforcement agencies were housed at WTC, in buildings 6 and 7. ATF had two vaults filled with tactical weapons and guns $(1,47,48)$. The ATF vaults were in WTC 6, where our samples 6 and 7 were measured. A total of 63 police officers died in the attack (11). They may have been carrying pistols equipped with tritium night sights. In fact, many guns have been recovered from the debris $(47,48,49)$, some of them in good condition. It would take 20 equipped weapons destroyed, $50 \mathrm{mCi}$ each, to give approximately $1 \mathrm{Ci}$ of tritium (Section 4).

Considering that there were 2823 victims in the attack, tritium watches could have been another source of tritium. Tritium paint watches were less likely, since they contain much less tritium and are generally no longer manufactured in modern watches (Section 4). However, GTLS-type watches, although expensive, could have been worn by more affluent public of Lower Manhattan. In addition, the military-style watches may have been worn by the emergency/law enforcement personnel who perished. It would take 40 GTLS watches, $25 \mathrm{mCi}$ each, to give $1 \mathrm{Ci}$ of tritium activity. The GTLS watches can be obtained in specialty stores only. No specialty watch stores were located at WTC (50). Some watches, but not necessarily tritium, were recovered from the debris with only minor damage (49). Probability-wise, weapons were definitely present at WTC, and the law-enforcement types contain tritium night sights by design; tritium watches were probably present, but in numbers difficult to determine.

The mechanism of tritium release from either the weapons or watches would have been much different than from the airplanes. Some devices could have been catastrophically destroyed in the buildings collapse; however, surprisingly, many were recovered with only minor damage. In addition, GTLS weapon sights are well-encapsulated in metal protective shields. Many devices would have been subjected to smoldering fires of much lower temperature than the explosive and high-temperature fires up in the Towers (with the exception possibly of the WTC 7 fire). At such temperatures, GTLS tubes would soften and disfigure, slowly releasing tritium. Some of that tritium would diffuse from the debris and be dispersed in the air, while some would remain trapped in the debris. While oxidation of molecular tritium is slow in the air, tritium is known to adsorb on surfaces and exchange with the adsorbed monolayer of water to form HTO due to a catalytic action of the surface $(14,51,52,53)$. At elevated tritium concentrations, radiolytic and hot-atom chemistry effects also assist in the oxidation (21). Consequently, some molecular tritium released in the debris would convert to HTO and be swept with the hose and rain water down to the basement of the Bathtub, sharing the fate of HTO from the airplanes, but on a 
much slower time scale. This mechanism resembles leaching of HTO from landfills containing tritium RL devices (54).

\section{Modeling of Water Flow and Tritium Removal from Ground Zero}

A 3-Box model was developed to quantify water flow and tritium removal, depicted in Fig. 1. Box 0 describes the debris, from which HTO is assumed to be transferred to the flowing water at a rate $\lambda$. The Bathtub is divided into 2 boxes.

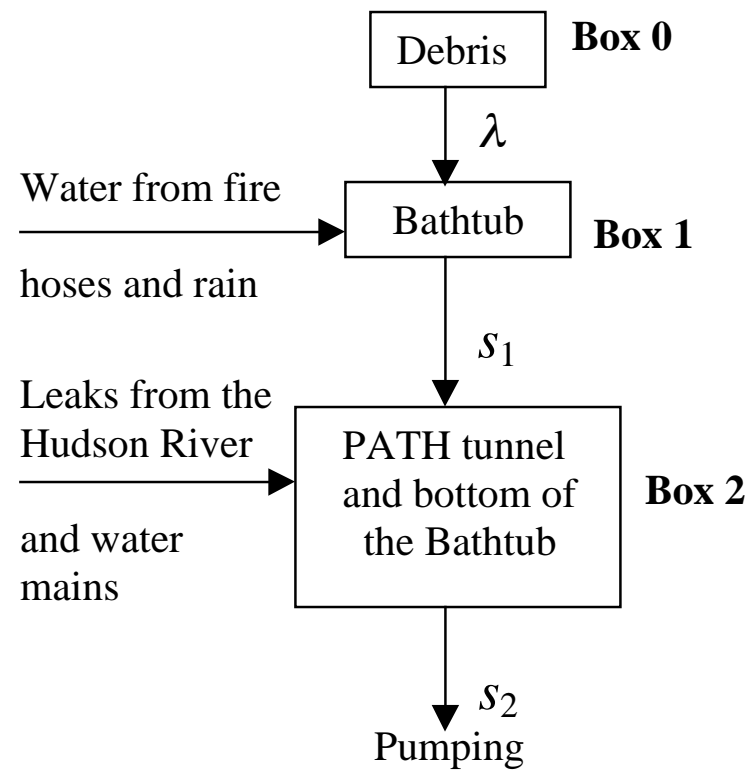

Figure 1. Model of water flow and tritium removal from the WTC.

Box 1 consists of 6/7 of the void volume of the Bathtub, through which $1.51 \times 10^{7} \mathrm{~L}$ of the hose and rain water flowed in 10 days. Therefore, an experimental flow rate $f_{1}=1.51 \times 10^{6} \mathrm{~L} /$ day through Box 1 . Considering that the Bathtub was at least $50 \%$ destroyed and filled with the debris from the buildings (55), its air porosity could be assumed as 0.26 (a value for close packed spheres). For such porosity, the void volume can be calculated as $V_{1}=2.21 \times 10^{8} \mathrm{~L}$. It would take $V_{1} / f_{1}=146$ days for such a volume to propagate 
through Box 1. The experimental volume of water would not have even reached the bottom of the Bathtub in 10 days. We conclude that the water could not have filled the air porosity completely and what really mattered was the water, rather than the air porosity. Water would flow through filled small pores, however, it would flow only on the surfaces of larger voids. A reasonable estimate of the water-filled void volume can be made by equating it to the experimental volume of water that is known to have flowed in 10 days, $V_{1}=1.51 \times 10^{7} \mathrm{~L}$. This yields a water flow time constant $s_{1}=f_{1} / V_{1}=0.1 /$ day for Box 1 .

The B6 level with the PATH tunnel is taken as Box 2. One could estimate an upper limit for the water porosity as 0.1 . Its exact value is less important for the model, since the experimental water flow rate through Box $2, f_{2}=1.14 \times 10^{7}$ L/day > $f_{1}$. This yields $V_{2}=1.42 \times 10^{7} \mathrm{~L}$, and the water flow time constant $s_{2}=f_{2} / V_{2}=0.803 /$ day for Box 2 .

The following differential equations describe tritium propagation through the three boxes at ground zero, for a general tritium source:

$$
\begin{aligned}
\frac{d A}{d t} & =-\lambda A, \\
\frac{d c_{1}}{d t} & =\frac{\lambda}{V_{1}} A-s_{1} c_{1}, \\
\frac{d c_{2}}{d t} & =\frac{f_{1}}{V_{2}} c_{1}-s_{2} c_{2},
\end{aligned}
$$

where $t$ is the time, $A$ is the total tritium activity in the debris, and $c_{1}, c_{2}$ are HTO concentrations in Boxes 1 and 2, respectively. Equations (1a-1c) are linear, $1^{\text {st }}$ order, of which (1b) and (1c) are inhomogeneous. They can be solved by standard methods (56), resulting in the following equation describing the measured HTO concentration $c_{2}$ at the bottom of the Bathtub:

$$
c_{2}=\frac{s_{1} \lambda A_{0}}{V_{2}}\left(\frac{e^{-\lambda t}}{\left(s_{1}-\lambda\right)\left(s_{2}-\lambda\right)}+\frac{e^{-s_{1} t}}{\left(\lambda-s_{1}\right)\left(s_{2}-s_{1}\right)}+\frac{e^{-s_{2} t}}{\left(\lambda-s_{2}\right)\left(s_{1}-s_{2}\right)}\right) \text {, }
$$

where $A_{0}$ is the total HTO activity from a general tritium source at time zero.

Equation (2) needs to be simplified for the specific sources, using the approximation $e^{-s_{1} t}>>e^{-s_{2} t}$, which is based on the experimental condition 
$s_{2}>s_{1}$. For the source term from the airplanes, tritium was in HTO form in the debris (Section 5) and its removal would be controlled solely by the flow rate (the slowest process) in Box 1, rather than by the transfer rate $\lambda$. We thus set $\lambda>>s_{2}$, and obtain from Eq. (2)

$$
A_{0}=c_{2} f_{2}\left(1 / s_{1}-1 / s_{2}\right) e^{s_{1} t}
$$

Using $c_{2}=3.18 \mathrm{nCi} / \mathrm{L}, t=10$ days, and the values $s_{1}$ and $f_{2}$ given above, we obtain $A_{0}=0.86 \mathrm{Ci}$ from Eq. (3). Taking the total tritium activity of $34 \mathrm{Ci}$ from the two airplanes implies an upper limit for the HTO deposition fraction of $2.5 \%$. This fraction, although the right order of magnitude, is high by a comparison with the two tritium fire incidents described in Section 5, indicating that the airplane source alone was insufficient.

For the tritium source term from the weapons subjected to the smoldering fires, tritium removal would be controlled by the transfer rate from the debris (the slowest process). We thus set $s_{1}>>\lambda$, and obtain from Eq. (2)

$$
A^{0}=\frac{c_{2} f_{2}}{\lambda\left[1-e^{-\left(s_{1}-\lambda\right) t}\right]} .
$$

Equation (4) cannot be solved uniquely with one value of $c_{2}$. There is, however, a constraint $s_{1}>>\lambda$. Taking $\lambda=0.1 s_{1}$ would imply $A_{0}=6.1 \mathrm{Ci}$. Such activity of tritium could be generated by 120 equipped weapons, $50 \mathrm{mCi}$ each. It is thus an entirely reasonable scenario, however it is to too high since it would require a complete destruction of 120 weapons and a quantitative tritium capture as well as a conversion to HTO. Taking $\lambda$ larger would invalidate experimental conditions for this source. Taking $\lambda$ even smaller would further overestimate this tritium source. Therefore, such a mechanism alone was not sufficient and another tritium source must have been present, which were the airplanes.

\section{Conclusions}

$34 \mathrm{Ci}$ of tritium were released from the emergency tritium RL signs onboard the two Boeing 767s, on impact with the Twin Towers at the WTC. The measurements and modeling are consistent with a prompt creation of HTO in the jet-fuel explosion and fire, deposition of a small fraction of HTO at ground zero, and water-flow controlled removal from the site. The modeling implies that the contribution from the aircraft alone would yield the HTO deposition fraction of $2.5 \%$. This value is too high by a comparison with other incidents involving fire 
and tritium. Therefore, the source term from the airplanes alone is too small to explain the measured concentrations, and another missing source is needed.

There is evidence that weapons belonging to federal and law-enforcement agencies were present and destroyed at the WTC. Such weapons contain tritium sights by design. The exact activity of tritium from the weapons was not determined. The data and modeling are consistent with the tritium source from the weapon sights (plus possibly tritium watches) in the debris, from which tritium was slowly released in the lingering fires, followed by an oxidation and removal with the water flow. Our modeling suggests that such a scenario would require a minimum of 120 equipped weapons destroyed and a quantitative capturing of tritium, which is too high, since many weapons were found with only minor damage and tritium sights are shielded in a metal. Therefore, such a mechanism alone is not sufficient to account for the measured HTO concentrations. This indicates that the weapons/watches are consistent with the missing source, which would have complemented the airplane source.

\section{Acknowledgments}

The following individuals are highly acknowledged for their substantial contributions to the overall success of this work: D. McChesney, EPA Region 2, for collecting group-1 samples; V. Murray and R. Pirritano, New York City Department of Environmental Protection, for collecting group-2 samples; E. Regilski and C. Schwenker, New York State Department of Health, for their help in the sample analysis and measurements; D. Dischino, Bristol-Myers Squibb Corporation, for scientific discussions on tritium; F. Lombardi, Port Authority of New York and New Jersey, for information about emergency EXIT signs at the WTC, as well as estimation of the total water flow rate at the WTC; T. Headley, Fire Department of New York, for estimation of water flow rate due to fire fighting at the WTC; J. Cashdollar and N. Sabatini, Federal Aviation Administration, for the estimation of tritium activity onboard the aircraft; J. Gaver, US Department of Energy, and C. Skinner, Princeton Physics Plasma Laboratory, for their expertise on tritium chemistry at high temperatures; R. Pause and A. Verschoor, New York State Department of Health, for critical reading of the manuscript.

\section{References}

Disclaimer: The statements and conclusions in this paper are those of the authors and not necessarily those of the New York State Department of Health State, State University of New York, Lawrence Berkeley National Laboratory, 
Lawrence Livermore National Laboratory, or Westinghouse Savannah River Company. The mention of commercial vendors, products, and news media in connection with the work reported herein is not to be construed as either actual or implied endorsement of such vendors, products, or media.

$\square^{\square}$ Corresponding author: Thomas Semkow, Wadsworth Center, New York State Department of Health, Empire State Plaza, Albany, NY 12201-0509. Email: semkow@wadsworth.org.

1. Miller, J. Digging for gold, guns and drugs. American Broadcasting

Corporation, abcnews.go.com, 10/3/2001.

2. Cummings, S. WTC complex: 6WTC, 7WTC. Patriot Resource, www.patriotresource.com, 2002.

3. Overbye, D. Engineers tackle havoc beneath Trade Center. New York Times, www.nytimes.com, 9/18/2001.

4. Lombardi, F.J. Response at ground zero - role of engineers. National Engineers Week 2002, Fishkill, NY, 2/19/2002.

5. Associated Press. Engineers study WTC collapse. New York Times, www.nytimes.com, 4/30/2002.

6. Ashley, S. When the Twin Towers fell. Scientific American, www.sciam.com, 10/9/2001.

7. Lipton, E.; Glanz, J. First Tower to fall was hit at higher speed, study finds. New York Times, www.nytimes.com, 2/23/2002.

8. Slobin, S. W.T.C.: Clearing the debris. New York Times, www.nytimes.com, 10/13/2001.

9. Glanz, J.; Lipton, E. Burning diesel is cited in fall of $3^{\text {rd }}$ tower. New York Times, www.nytimes.com, 3/2/2002.

10. Lipton, E.; Glanz, J. A nation challenged: forensics; DNA science pushed to the limit in identifying the dead of Sept. 11. New York Times, www.nytimes.com, 4/22/2002.

11. List of officers missing or killed in the line of duty during the attacks in New York. International Union of Police Associations, www.iupa.org, 2001.

12. Okada, S.; Momoshima, N. Overview of tritium: characteristics, sources, and problems. Health Phys. 65: 595-609, 1993.

13. Hill, R.L.; Johnson, J.R. Metabolism and dosimetry of tritium. Health Phys. 65: 628-647, 1993.

14. Traub, R.J.; Jensen, G.A. Tritium radioluminescent devices. Health and safety manual. Pacific Northwest National Laboratory Report PNL-10620 (UC-610), Richland, WA, 1995.

15. Bennett, B.G. Worldwide dispersion and deposition of radionuclides produced in atmospheric tests. Health Phys. 82: 644-655, 2002.

16. Environmental radiation data. US Environmental Protection Agency, Report 81, EPA-402-R-97-004, 1997. 
17. Maximum contaminant levels for radionuclides. US Code of Federal Regulations, 40 CFR Part 141.66.

18. Local climatological data. National Oceanic and Atmospheric Administration, US Department of Commerce, September 2001.

19. Lulu, B. Luminous watch hands. Power Reserve Inc., www.timezone.com, 11/19/1998.

20. Niemeyer, R.G. Tritium loss from tritium self-luminous aircraft exit signs. Oak Ridge National Laboratory Report ORNL-TM-2539, Oak Ridge, TN, 1969.

21. Wermer, J.R. Assessment of commercial self-luminous exit signs containing tritium: Final Report - Task 1. Westinghouse Savannah River Company Report WSRC-TR-0311, Aiken, SC, 1995.

22. Classification of Radioactive self-luminous light sources. American National Standard ANS/HPS N43.4, American National Standards Institute/Health Physics Society, McLean, VA, 2000.

23. Luminous safety devices for use in aircraft: Requirements for license to manufacture, assemble, repair or initially transfer. US Code of Federal Regulations, 10 CFR Part 32.53.

24. Trijicon Inc., www.trijicon.com, 2002.

25. Innovative Weaponry Inc., personal communication, 3/18/2002.

26. Kinder, K. Kimber of America Mfg. Inc., personal communication, 3/19/2002.

27. Certain items containing byproduct material. US Code of Federal Regulations, 10 CFR Part 30.15 .

28. License applications for certain items containing byproduct material. US Code of Federal Regulations, 10 CFR Part 32, RIN 3150-AF76.

29. Radioluminescence for time measurement instruments - specifications. International Standard 3157, International Organization for Standardization, Geneva, Switzerland, 1991.

30. Watch, wrist: general purpose. US Military Specification MIL-W-46374F, Naval Publications and Forms Center, Philadelphia, PA, 1991.

31. Benziger, J. Mb-microtec ag, personal communication, 3/19/2002.

32. Zeller, A. Rc Tritec ag, personal communication, 3/18/2002.

33. Lombardi, F.J. Port Authority of New York and New Jersey, personal communication, 12/10/2001.

34. Sabatini, N.A. Federal Aviation Administration, US Department of Transportation, personal communication, 3/26/2002.

35. Cashdollar, J. Federal Aviation Administration, US Department of Transportation, personal communication, 4/23/2002.

36. Pan, P.Y.; Rigdon, L.D. Tritium oxidation in atmospheric environment. Los Alamos National Laboratory Report LA-UR-96-2953, Los Alamos, NM, 1996. 
37. Gaver, J.M. Savannah River Site, US Department of Energy, personal communication, 1/30/2002.

38. Skinner, C.H.; Gentile, C.A.; Carpe, A.; Guttadora, G.; Langish, S.; Young, K.M.; Shu, W.M.; Nakamura, H. Tritium removal from codeposits on carbon tiles by a scanning laser. J. Nucl. Mater. 301: 98-107, 2002.

39. Jensen, G.A.; Martin, J.B. Investigation of fire at Council, Alaska: A release of approximately 3000 curies of tritium. Pacific Northwest National Laboratory Report PNL-6523, Richland, WA, 1988.

40. Health physics sampling results, C-124 incident. Bio-environmental Engineering Branch, US Air Force Hospital Wright-Patterson Report AFR 11-30, Wright-Patterson Air Force Base, OH, 1965.

41. Duenes, S. Hot spots linger at ground zero. New York Times, www.nytimes.com, 10/2/2001.

42. Headley, T. Fire Department of New York, personal communication, 2/12/2002.

43. Post, N.M. Engineers plan assessment and new support for WTC foundation perimeter walls. Engineering News Record, www.enr.com, 9/17/2001.

44. Cho, A.; Post, N.M. Crews shore damaged subways. Engineering News Record, www.enr.com, 10/8/2001.

45. Post, N.M. WTC 'Bathtub' stabilization begins. Engineering News Record, www.enr.com, 10/29/2001.

46. Lombardi, F.J. Port Authority of New York and New Jersey, personal communication, $1 / 28 / 2002$.

47. World Trade Center rubble holds buried secrets. WPVI, abclocal.go.com, Philadelphia, PA, 10/5/2001.

48. Gardiner, S.; Hurtado, P. Billions in stocks, bonds found in WTC rubble. Seattle Times, seattletimes.nwsource.com, 10/6/2001.

49. Koppel, T. Ground zero. American Broadcasting Corporation, Nightline, abcnews.go.com, 3/11/2002.

50. NYNEX Directory for New York Metro Area. NYNEX, 4/1995 - 3/1996.

51. Ono, F.; Tanaka, S.; Yamawaki, M. Sorption and desorption of tritiated water on paints. Fusion Tech. 21: 827-832, 1992.

52. Dickson, R.S.; Miller, J.M. Sorption of tritium and tritiated water on construction materials. Fusion Tech. 21: 850-855, 1992.

53. Antoniazzi, A.B.; Shmayda, W.T.; Surette, R.A. Decontamination of stainless steel. Fusion Tech. 21: 867-871, 1992.

54. Hicks, T.W.; Wilmot, R.D.; Bennett, D.G. Tritium in Scottish landfill sites. Galson Science Report 014-2, Rutland, UK, 2000.

55. Post, N.M. Half of WTC 'Bathtub' basement damaged by Twin Towers' fall. Engineering News Record, www.enr.com, 10/8/2001.

56. Margeneau, H.; Murphy, G.M. The mathematics of physics and chemistry. Krieger Publishing Co., Huntington, NY, 1976. 